\title{
黒鉛炉原子吸光法による植物試料中の コバルト及びニッケルの定量
}

\author{
斉 文 啓*，古谷 圭一**，合志 陽一®***
}

(1986 年 12 月 13 日受理)

\begin{abstract}
黑鉛炉 AAS による Co 及び Ni の定量法につき検討し, 茶葉, 植物武料 (NBS SRM Orchard Leaves, Spinach) 中の Co, Ni の定量に応用した。植物試料中に微量で存在している Co, Ni は, 添 加凰としてトリオキソバナジン $(\mathrm{V})$ 酸アンモニウムを加えることにより, 濃縮, 共存物質の 分離など の前処理なしに，直接定量可能であった。本方法によって NBS SRM 1571 と 1570 の Co を定量し た結果， 0.19 と $1.35 \mu \mathrm{g} / \mathrm{g}$ であり，参考值の $0.2 ， 1.5 \mu \mathrm{g} / \mathrm{g}$ と良く一致した. Ni の絆果については, $1.22,5.68 \mu \mathrm{g} / \mathrm{g}$ であり， $1.3 \pm 0.2 \mu \mathrm{g} / \mathrm{g}$ の表示值あるいけ $6 \mu \mathrm{g} / \mathrm{g}$ の参考值と良く一致した。本方法 の相対標準偏差は Co 及び Ni に対してそれぞれ $0.42 〜 1.80 \%$ 及び $0.89 〜 4.80 \%$ である。溶媒抽 出/黑鉛灯 AAS などの定量法より簡便，迅速であり，かっ定量精度も良かった。
\end{abstract}

\section{1 緒言}

生体中の Ni 及び Co は必須元素に分類され，生物の 健康の維持及び正常な代謝生理機能の維持に大きな重要 性を有することが知られている.

Ni と関しては，生体中のデオキシリボ核酸やリボ核 酸中に存在することが知られ, 核酸の熱力学的安定性を 維持する効果があると言われている. 又, Co はビタミ ン $\mathrm{B}_{12}$ の主な成分であり，この欠乏は貧血をもたらす。

植物に対する微量の Ni 及び Co の効果については, 添加による生長促進が認められている1)2).

他方, これらの元素は, 工業原材料, 触媒などとして 多量飞使用されて扣り，これらの蓄積についても新しい 環境污染物質として, 検討を進める必要があり，その迅 速かつ正確な定量方法の研究が進められている.

生体試料中の $\mathrm{Ni}$ 及び Co を定量するための従来の 方法としては, 試料を灰化後, 溶液化し，これを $5 \mathrm{Br}$ PADAP 法3)，二トロソ R 塩法4)， ニトロソクレゾール 法及びジメチルグリオキシム法5)などの比色法により測 定する方法が利用されている.しかし，これらの元素は 生体中の存在量が極めて微量である場合には適用できな

* 中国科学技術大学: 中華人民共和国合肥市

** 東京理科大学理学部応用化学科 : 162 東京都新宿 区神楽坂 1-3

*** 東京大学工学部工業化学科：113 東京都交京区本 郷 7-3-1
W.

近年, フレームレス AASによる生物試料中の各元素 の定量が検討されている. この方法は簡便かつ迅速に測 定できる利点はあるが, 試料灰化後に溶液化処理を行っ た場合，溶液中の共存物質による干渉が大きく，そのま ま測定に供することは不可能な場合がある.このため, 重水素ランプによるバックグラウンドの補正, 溶媒抽出 などによる干渉物質の除去について検討がなされてい る. 微量の $\mathrm{Ni}$, Co の溶媒抽出については, これまで 報告された方法は1-(2-ピリジルアゾ)-2-ナフトール (PAN)，5Br-PADAP, DDTG, APDC, $\alpha \beta-N N$ などが ある6 10). 札川らは99選択性及び抽出性の良好な 1 -二ト ロソ-2-ナフトールを用い，m-キシレンを抽出溶媒として 植物中の $0.20 \mathrm{ppm}$ の Co を定量し, 更に, 抽出試薬 としてフリルジオキシムを用い, $m$-キシレンで抽出し, $\mathrm{Ni}(1.30 \mathrm{ppm})$ を測定した ${ }^{10)}$.

本報告では，黒鉛炉 AAS で植物中の $\mathrm{Ni}$, Co を定 量する際に, 試料溶液中に添加剤としてトリオキソバナ ジン $(\mathrm{V})$ 酸アンモニウムを加えると, 灰化を行う際高温 でも $\mathrm{Ni}$, Co の散失がなく, 妨害元素は揮散することを 明らかにした。 この添加剤を用いることにより, 分離及 び濃縮操作を行わない直接定量が可能となった．更にこ の方法を, 茶葉, Orchard Leaves (NBS SRM 1571), Spinach (NBS SRM 1570) の Ni, Co の定量に応用し た. 


\section{2 装置及び試薬}

\section{1 装置及び測定条件}

装置は泉津 AA-640 型，间時補正装置付き炭素管》 トマイザー GFA-4 型を用いた。光源は Ni, Co 中空陰 極ランプを用い，义，バックグラウンドの補正には，重 水素放電ランプを用いた。武料の導入には，10 $\mu \mathrm{l}$ のマ イクロピペットを使用した。

測定条件は，Table 1 のように設势した。これは 3 に 述べる実験により，トリオキソバナジン $(\mathrm{V})$ 酸アンモニ ウムを添加した武料について最も良い結果を与える条件 であり，本報告中の測定值は特記した場合以外はすべて これらの条件で得られたものである。

Table 1 Atomic absorption spectrophotometer (AA-640, GFA-4) setting for anaylsis of $\mathrm{Co}$ and $\mathrm{Ni}$ in plant

\begin{tabular}{|c|c|c|}
\hline \multicolumn{3}{|l|}{ AA -640} \\
\hline \multicolumn{2}{|c|}{ Light source : Co } & H.C.L \\
\hline \multicolumn{2}{|c|}{ Lamp source : $8 \mathrm{~mA}$} & $9 \mathrm{~mA}$ \\
\hline \multicolumn{2}{|c|}{ Wavelength : $240.7 \mathrm{~nm}$} & $232.0 \mathrm{~nm}$ \\
\hline Bandwidth & $: 1.9 \AA$ & $1.9 \AA$ \\
\hline \multicolumn{3}{|l|}{ GFA-4 } \\
\hline Drying & $: 130^{\circ} \mathrm{C}, 30 \mathrm{~s}$ & \\
\hline Ashing & $: 800^{\circ} \mathrm{C}, 25 \mathrm{~s}$ & \\
\hline Atomizing & $: 2200^{\circ} \mathrm{C}, 5 \mathrm{~s}$ & \\
\hline $\mathrm{Ar}$ & $: 11 / \mathrm{min}$ & \\
\hline
\end{tabular}

\section{2 試 薬}

ニッケル，コバルト標準溶液 $(1000 \mathrm{ppm})$ はAAS 用 (関東化学製) 標準溶液を用いた。干涉イオンや添加剤 として検討したものは，特級試薬を用いて各々必要な濃 度に調製したものである。酸は，すべて特級試薬を使用 した。

\section{3 結果及び考察}

\section{1 添加イオンの効果}

$\mathrm{Ni}$ と Co の定量に増感作用があると予想される塩類 を選び，これらの増感作用を調べた．垁験溶液は， 60 $\mathrm{ppb}$ の $\mathrm{Ni}, 40 \mathrm{ppb}$ の Co 及び $0.2 \%$ 添加剤を含むも のを用いた. その絬果を Table 2 にまとめた. 既に報 告されている白金族の $\mathrm{Pt}, \mathrm{Rh}, \mathrm{Pd}$ の増感効果も観測さ れたが, Mo, W， V の酸素酸塩の増感効果のほうが優 れている. 更に，同じモリブデンイオンでも，添加する 塩が異なると, 增感効果の相違が見られた. Table 2 に 示すように，モリブデン酸アンモニウムの増感が認めら れたが，硫酸アンモニウムとシュウ酸アンモニウムの効 果は認められなかった. テトラオキソバナジン (V) 酸 ナトリウムとトリオキソバナジン $(\mathrm{V})$ 酸アンモニウム
Table 2 Enhancement effect of additional ion as a matrix modifier on the absorbances for Co and $\mathrm{Ni}$

\begin{tabular}{llll}
\hline \multirow{2}{*}{ Additives } & $\begin{array}{c}\text { Forms, } \\
0.2 \%\end{array}$ & \multicolumn{2}{c}{$\begin{array}{c}\text { Relative atomic } \\
\text { absorption }\end{array}$} \\
\cline { 3 - 4 } & & \multicolumn{2}{c}{$\begin{array}{c}\mathrm{Co} \\
\mathrm{Ni}\end{array}$} \\
\hline $\mathrm{None}$ & & 100 & 100 \\
$\mathrm{Mo}$ & $\left(\mathrm{NH}_{4}\right)_{6} \mathrm{Mo}_{7} \mathrm{O}_{24}$ & 110 & 109 \\
& $\mathrm{MoCl}_{5}$ & 104 & 105 \\
$\mathrm{Pt}$ & $\mathrm{Na}_{2} \mathrm{PtCl}_{6}$ & 115 & 100 \\
& $\mathrm{PtCl}_{4}$ & 114 & 102 \\
$\mathrm{Rh}$ & $\mathrm{RhCl}_{3}$ & 107 & 109 \\
$\mathrm{Pd}$ & $\mathrm{PdCl}_{2}$ & 105 & 105 \\
$\mathrm{~W}$ & $\mathrm{Na}_{2} \mathrm{WO}_{4}$ & 120 & 111 \\
$\mathrm{SO}_{4}{ }^{2-}$ & $\left(\mathrm{NH}_{4}\right)_{2} \mathrm{SO}_{4}$ & 101 & 102 \\
$\mathrm{C}_{2} \mathrm{O}_{4}{ }^{2-}$ & $\left(\mathrm{NH}_{4}\right)_{2} \mathrm{C}_{2} \mathrm{O}_{4}$ & 100 & 101 \\
$\mathrm{~V}$ & $\mathrm{Na}_{3} \mathrm{VO}_{4}$ & 134 & 121 \\
& $\mathrm{NH}_{4} \mathrm{VO}_{3}$ & 141 & 152 \\
\hline
\end{tabular}

の増感効果が最も大きい.しかし，テトラオキソバナジ ン(V) 酸ナトリウムを添加した場合は，他に比べて測定 精度が悪いことも分かった．以上の結果から，添加剤と してトリオキソバナジン $(\mathrm{V})$ 酸アンモニウムを用いる こととした.

\section{2 添加剤の量}

トリオキソバナジン $(\mathrm{V})$ 酸アンモニウムの増感効果 と添加量との関係を検討した. $60 \mathrm{ppb}$ の $\mathrm{Ni}$ と $40 \mathrm{ppb}$ の Co を含む溶液に，トリオキソバナジン $(\mathrm{V})$ 酸アンモ ニウムを $0.05,0.1,0.2,0.3,0.4,0.5$ 及び $1.0 \%$ 含 む溶液を添加し測定を行った，その結果，トリオキソバ ナジン $(\mathrm{V})$ 酸アンモニウムの添加量が $0.1 \sim 0.4 \%$ であ れば， Ni，Co の吸光度は一定となり，1.0\% 以上では 再現性が悪くなることが分かった。これは, 添加によっ て生ずるバックグラウンドや記憶効果によるものと考え られる. 以上の結果に基づき，トリオキソバナジン $(\mathrm{V})$ 酸アンモニウムの添加量は $0.2 \%$ とした. なおここの 添加量では, 溶液の粘度も变化せず, 試料注入後マイク ロピペットの先端に溶液が残るという問題も起こらなか った.

\section{3 灰化温度}

札川ら 910)によると，死化温度 $600^{\circ} \mathrm{C}$ 以上では死化 過程で $\mathrm{Co}$ が揮散し, $\mathrm{Ni}$ は $650^{\circ} \mathrm{C}$ 以上で真の值より 低い值を示し始める，一方，灰化温度が低すぎると，原 子化過程の初期に大きなバックグラウンド吸収が現れ， 誤差の原因となる・マトリックスの影響も效果的に除去 するため，更に高温で灰化することが必要である．本研 
究では，トリオキソバナジン $(\mathrm{V})$ 酸アンモニウムを加 えたため，灰化反応及び原子化機構が変化することが予 想される. 灰化温度の定量値に与える影響を調べるため に, 試料溶液を 各温度で 25 秒間灰化した後, $2300{ }^{\circ} \mathrm{C}$ で 5 秒間原子化し，ピーク吸光度を測定した。 その結果 を Fig. 1 に示した. トリオキソバナジン (V) 酸アンモ ニウムを添加した場合， $1100{ }^{\circ} \mathrm{C}$ までは吸光度は高い值 を示し, 又, Ni と Co が散失しないことが分かった。

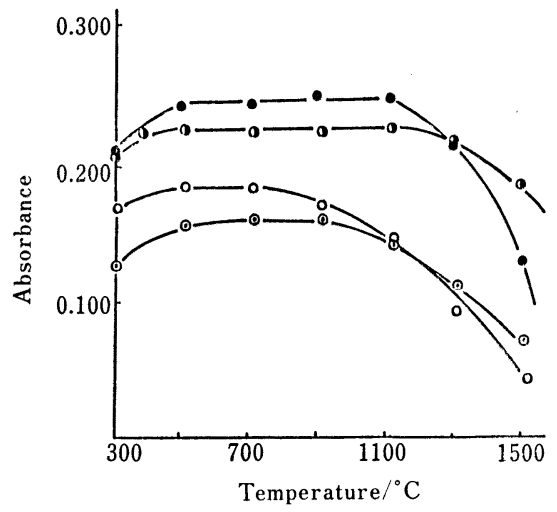

Fig. 1 Effect of ashing temperature on atomic absorption of $\mathrm{Co}$ and $\mathrm{Ni}$

$\bigcirc: 40 \mathrm{ppb} \mathrm{Co} ; \bigcirc \mathrm{Co}+\mathrm{NH}_{4} \mathrm{VO}_{3} ; \odot: 60 \mathrm{ppb}$ $\mathrm{Ni} ; \mathrm{O}: \mathrm{Ni}+\mathrm{NH}_{4} \mathrm{VO}_{3}$

この結果から, 以降の実験に打ける灰化温度を $800^{\circ} \mathrm{C}$ とした.

本研究では, $\mathrm{Ni}$ の微量分析中に拈いて通常使用され ている吸収極大波長 $2320.0 \AA$ の共鳴線を用いるが， $\mathrm{Ni}$ のイオン線である $2319.8 \AA$ の干渉によりバックグラウ ンドが高くなり，感度も低下する．又，低温灰化の場合 は, 粒子の大きい塩類, 共存物の粒子が生成し, 光源か らの光が散乱されるが，トリオキソバナジン $(\mathrm{V})$ 酸アン モニウムを添加した場合には，高温でトリオキソバナジ ン(V) 酸ニッケルが生成するため， Ni のイオン化が防 止され，同時に，共存塩類のマトリックスが除去される といら効果が得られた。

Co の定量の際にも同様な問題がある.すなわち，Co の吸収極大波長の $2407.3 \AA$ に対し近接するスペクトル 線である Co のイオン線 $2407.7,2408.8 \AA$ が $2 \AA$ の バンド幅程度の設定では妨害となる. 一方バンド幅が小 さすぎると，シグナルも小さくなり， $S / N$ が減少する原 因となる．これに対して同様な理由で，トリオキソバナ ジン(V) 酸アンモニウムを添加すれば, Co のイオン化
が防止され，又，共存元素を除去することができた．

\section{4 原子化条件の選択}

灰化温度を $800{ }^{\circ} \mathrm{C} ， 25$ 秒間とし，原子化時間を 5 秒 とした際の原子化温度の影響を調べるために，原子化温 度を $1800^{\circ} \mathrm{C}$ から $2500{ }^{\circ} \mathrm{C}$ をで変化させて, 上記の試 料溶液を用い，ピーク吸光度を 測定した. この結果を Fig. 2 に示した.

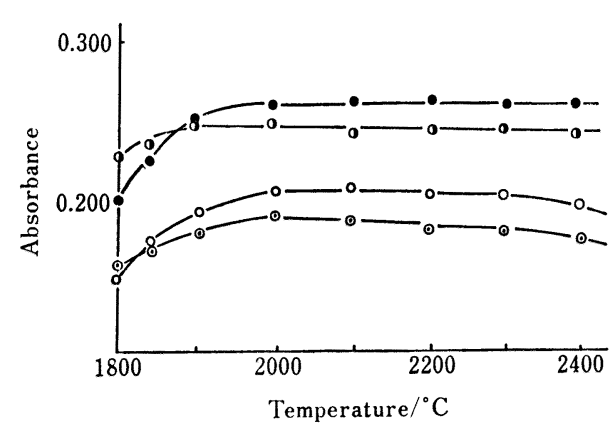

Fig. 2 Effect of atomization temperature on atomic absorption of $\mathrm{Co}$ and $\mathrm{Ni}$ $\bigcirc: 40$ ppb Co; $\odot: 60$ ppb Ni; $\bigcirc \mathrm{Co}+$ $\mathrm{NH}_{4} \mathrm{VO}_{8} ; \quad \mathrm{Ni}+\mathrm{NH}_{4} \mathrm{VO}_{3}$

原子化温度の上昇と共に，ピークの形状は鋭くなり， 吸光ピークの高さも徐々に増加する.トリオキソバナジ ン $(\mathrm{V})$ 酸アンモニウムを添加しない場合には, 原子化温 度が $2000 \sim 2100 C^{\circ}$ 以上で, ピーク吸光度が徐々に減 少するのが観測された. 一方トリオキソバナジン (V) 酸アンモニウムを添加した場合には，原子化温度の最適 範囲は $2000 〜 2300^{\circ} \mathrm{G}$ に広がった。これは, 原子化過程 が変化したためと考えられる．以上の結果に基づき，原 子化条件を $2200^{\circ} \mathrm{C} ， 5$ 秒間とした.

\section{5 共存イオンの影限}

通常の植物に 含まれると考えられる 主な元素の 0.30 $\mathrm{ppm}$ の $\mathrm{Ni}$ と $0.10 \mathrm{ppm}$ の Co の定量に及ぼす干渉効 果について調べた. 又, 試料を調製するときに使用する 酸による効果も検討した.

硫酸，リン酸，過塩素酸は灰化，原子化過程で白煙を 発生し，定量值に影響を及ぼす可能性があるので，好ま しい酸ではない. 特に, 硫酸、リン酸の場合は, 次ら の濃度が $2.5 \%$ 以上であると，溶液の粘度が高くなり， 試料注入時に溶液がマイクロピペットの先端に残り, 誤 差を生じやすい，塩酸の場合， $\mathrm{Ni} ， \mathrm{Co}$ は塩化物として 
揮発しやすいため, 添加剤と高温灰化を利用する直接定 量法に不適当と思われる. 硝酸は 0.5 4.5\% の範囲 で， Ni，Co の兟量結果に影響も及ぼさないことが分か った. 従って, 本研究では用いる標準溶液及び試料溶液 は $0.5 \%$ 硝酸とした。

上述条件では, トリオキソバナジン $(\mathrm{V})$ 酸アンモニウ 厶学添加した場合には，0.30 ppm の Ni と $0.10 \mathrm{ppm}$ の Co の定量に刘して, $\mathrm{K}(1600 \mathrm{ppm}), \mathrm{Na}(300), \mathrm{Ca}$ (270), $\mathrm{Fe}(135), \mathrm{Mg}(200), \mathrm{Mn}(195), \mathrm{Cu}(1.5), \mathrm{Zn}$ (3.0) 坟びモリブデン (VI) 酸, 塩化白金酸, テトラォ キソタングステン $(\mathrm{VI})$ 酸, トリオキソバナジン $(\mathrm{V})$ 酸 など $500 \mathrm{ppm}$ の陰イオン, $200 \mathrm{ppm}$ の $\mathrm{Rh}(\mathrm{III}), \mathrm{Pd}$ (II), $\mathrm{Pt}(\mathrm{IV})$ などの共存イオンによる影響は認められな かった.

トリオキソバナジン $(\mathrm{V})$ 酸アンモニウムを加えない 場合について，直接定量法により， $\mathrm{Ni} ， \mathrm{Co} を$ 測定した ところ, $\mathrm{Ca}, \mathrm{K}, \mathrm{Na}$ 各イオンが共存すると, 発光のた めと考えられる7) バックグラウンドが強く，重水素ラン プで補正できず，測定は代叮能であった.

$50 \sim 300 \mathrm{ppm}$ の $\mathrm{Al}$ の共存について, $\mathrm{Ni}$ の測定に対 しては，干涉が諗められなかったが，Co の測定に負の 愦差を与えることが諗められた。この汗涉は, Ure ら が報告した光散乱によるスペクトル干渉が大きいとする 結果と良く一致している．すなわち，Co に Al を共存 させた場合, 吸光度低トや分子吸収が大きい。ただし， $50 \mathrm{ppm}$ から $200 \mathrm{ppm}$ までの $\mathrm{Al}$ が共存する場合, そ の干渉の効果は一定であった。これは $\mathrm{Al}$ の濃度が増す につれて，Co の吸光度が低下するが，光散乱はほぼ一 定であることを示している。この結果も又 Ure らの結 果と一致する.

$\mathrm{Al}$ の負干渉を補正するため，植物に含まれる $\mathrm{Al}$ 量 から計算して標準溶液に $100 \mu \mathrm{g} / \mathrm{ml}$ の $\mathrm{Al}$ を加え, そ の影響を一定のものとすることとした.

\section{6 検量線及び添加回収実験}

以上の検討の結果, $\mathrm{Ni}$ 及び $\mathrm{Co}$ の濃度がそれぞれ $0.074 \sim 7.72 \mathrm{ppm}, 0.015 \sim 1.88 \mathrm{ppm}$ の範囲で值線の検 量線が得られた。X，これらのこら配は標準添加法の検 量線とも良く一致した.

植物中の $\mathrm{Ni}$, Co の量について繰り返し測定したとこ ろ，本方法による测定值の 相対標準偏差は $\mathrm{Ni}$ の濃度 5.68〜1.22 ppm に対して0.89〜4.80\%であり, Coの 濃度 $0.081 \sim 1.35 \mathrm{ppm}$ に対して $0.42 \sim 1.80 \%$ であっ た。

なお，これとともに，回収実験も行った. $30 \mathrm{ppb} の$
Co を添加した際の 9 回の測定結果は $31 \sim 30 \mathrm{ppb}$ であ り，回収率は 103〜100\% であった. 又, $30 \mathrm{ppb} の \mathrm{Ni}$ を加えた測定結果は 29〜32 ppb であり，回収率は 97〜 107\% であった.

\subsection{Si の影響}

実験に使用した植物試料には，NBS SRM 1571 Orchard Leaves で $1.02 \mathrm{mg} / \mathrm{g}$, 茶葉で約 $0.65 \mathrm{mg} / \mathrm{g}$ の $\mathrm{Si}\left(\mathrm{SiO}_{2}\right.$ として) を含んでおり, 試料の分解過程で二 酸化ヶイ素となり， Ni と Co の定量を妨害し，低值も 与える. 又, $\mathrm{Si}$ を除去しない場合, $\mathrm{Ni}$, Co の相対標準 偏差は 1.3 と $6.0 \mathrm{ppm}$ の Ni に対して 15.9, 0.75\% であり， 0.2 と $1.5 \mathrm{ppm}$ の Co に対して 2.3，1.6\% 程度であった。

この原因に関しては，二酸化ケイ素による金属イオン の吸着が報告されている ${ }^{12)}$. Si の除去方法には, 二酸 化ヶイ素を汇別する方法, フッ化水素酸で揮散除去する 方法があるが, 前者は溶液量が増加するので, 後者の方 法を採用することとした。

4 茶葉, Orchard Leaves 及び Spinach の分解と $\mathrm{Ni}$, Co o定量

\section{1 乾式灰化}

札川ら9)の方法を参考にして, $105{ }^{\circ} \mathrm{C}$ で 2 時間乾燥し た試料の $1000 \mathrm{~g}$ を石英るつぼに採り, マッフル炉で $200{ }^{\circ} \mathrm{C} て ゙ 1$ 時間加熱灰化する。串に， $600{ }^{\circ} \mathrm{C}$ で 1 時間 加熱灰化し, 残留物に硝酸 $(1+1) 3 \mathrm{ml}$, 過塩素酸 $2 \mathrm{ml}$ を加え, 分解する. 分解液をテフロンビーカーに移し, $2 \mathrm{ml}$ のフッ化水素酸を添加し, $150{ }^{\circ} \mathrm{G}$ で白煙がほとん ど生じなくなるまで加熱蒸発する. 冷却後, $1 \%$ トリオ キソバナジン $(\mathrm{V})$ 酸アンモニウム $5 \mathrm{ml}$ と $0.5 \%$ 硝酸 を加光，析出物を加熱溶解する. もしマンガン化合物の 沈殿を生じ, 褐色を呈した場合, $1 \%$ 過酸化水素 1 滴を 添加し溶解する. $0.5 \%$ 硝酸で正確に $50 \mathrm{ml}$ とする.

\section{2 湿式灰化}

試料 $1000 \mathrm{~g}$ をテフロンビーカーに採り, 硝酸 $10 \mathrm{ml}$ を加え, 加熱分解した後, 過塩素酸 $5 \mathrm{ml}$ を添加し, 白 煙を発生させた後, フッ化水素酸 $2 \mathrm{ml}$ を添加し, 以下 乾式灰化と同様に処理し, 試料溶液とする.

\section{3 定}

$10 \mathrm{ml}$ のメスフラスコ中に $1 \mathrm{ml}$ の $1 \%$ トリオキソバ ナジン $(\mathrm{V})$ 酸アンモニウム及び $1 \mathrm{ml}$ の $1 \mathrm{mg} / \mathrm{ml}$ アル ミニウム溶液を加え, $\mathrm{Ni}$ 及び Co を一定量ずつ加え, 
$0.5 \%$ 硝酸で一定体積とした.

これらの溶液と試料溶液それぞれの $10 \mu \mathrm{l}$ をマイクロ ピペットで採取し，アトマイザーに注入し, Table 1 に 示した条件により， $\mathrm{Ni}$ と $\mathrm{Co}$ とのピーク吸光值を測定 する.その結果を Table 3 にまとめた.

Table 3 Determination of $\mathrm{Co}$ and $\mathrm{Ni}$ in plant materials $(\mu \mathrm{g} / \mathrm{g})$

\begin{tabular}{|c|c|c|c|c|c|c|c|}
\hline \multicolumn{2}{|r|}{ Sample } & \multicolumn{2}{|c|}{ Tea } & \multicolumn{2}{|c|}{$\mathrm{OL}^{\mathrm{a})}$} & \multicolumn{2}{|c|}{ Spinach $\left.^{b}\right)$} \\
\hline $\mathrm{HF}$ & treatment & no & yes & no & yes & no & yes \\
\hline \multirow[t]{2}{*}{ Co } & $\bar{X}$ & - & 0.081 & 0.017 & $0.19 c)$ & 1.13 & $1.35^{\mathrm{e})}$ \\
\hline & R.S.D., \% & - & 0.42 & 2.30 & 1.70 & 1.60 & 1.80 \\
\hline \multirow[t]{2}{*}{$\mathrm{Ni}$} & $\bar{X}$ & - & 4.68 & 0.87 & $1.22^{\mathrm{d})}$ & 4.30 & $\left.5.68^{f}\right)$ \\
\hline & R.S.D., \% & - & 4.30 & 15.9 & 4.8 & 0.75 & 0.89 \\
\hline \multirow[t]{2}{*}{$\operatorname{Cog})$} & $\bar{X}$ & & & & 0.18 & & 1.27 \\
\hline & R.S..D, \% & & & & 3.0 & & 13.1 \\
\hline \multirow[t]{2}{*}{$\left.\mathrm{Ni}^{\mathrm{h}}\right)$} & $\bar{X}$ & & & & 1.14 & & 6.21 \\
\hline & R.S.D., \% & & & & 9.8 & & 10.2 \\
\hline \multirow[t]{2}{*}{$\left.\mathrm{Ni}^{i}\right)$} & $\bar{X}$ & & & & 1.17 & & 5.58 \\
\hline & R.S.D., \% & & & & 3.8 & & 0.15 \\
\hline
\end{tabular}

a) NBS SRM 1571 Orchard Leaves, $n=5$; b) NBS SRM 1570 Spinach, $n=5$; c) non-certified value 0.2 $\mu \mathrm{g} / \mathrm{g}$; d) standard value $1.3 \pm 0.2 \mu \mathrm{g} / \mathrm{g}$; e) non-certified value $1.5 \mu \mathrm{g} / \mathrm{g}$; f) non-certified value $6 \mu \mathrm{g} / \mathrm{g}$; g) by extraction method with $5 \mathrm{Br}-\mathrm{PADAP} / \mathrm{MIBK}(n=$ $5)$; h) by extraction method with dimethylglyoxime$(n)$ amyl acetate $(n=5)$; i) by stripping method with $0.1 \mathrm{M} \mathrm{HCl} . \bar{X}$ : mean of ten determinations; R.S.D. : relative standard deviation.

なお，本方法と比較するため， $\mathrm{Ni}$ について，ジメチ ルグリオキシム-酢酸- $n$-アミル抽出 ${ }^{13)}$ ， Co について, 5Br-PADAP-MIBK 抽出を行って定量し ${ }^{14)}$, 結果も合 わせて Table 3 に示した（測定条件は札川ら910)を参 考にした).

Table 3 に示すと拈り, 両法の結果は, Spinach 中の Co がやや低值であることを除いては, NBS 参考值に極 めて良く一致し，トリオキソバナジン $(\mathrm{V})$ 酸アンモニ ウムを用いた結果の精度は極めて良く, 又, 操作性にお いても他法に比べて優れていることが分かった.

終わりに，本研究を行うに当たり，御世話になった東 京大学理学部不破敬一郎教授, 刘平氏, 同工学部福 島 整氏, 東京理科大学理学部渡辺友治氏に深く感謝し ます。

\section{文献}

1) T. C. Hutchinson : "Effect of Heavy Metal Pol- lution on Plants", Edited by N. W. Lepp, p. 171 (1981), (Applied Science Pub., London).

2) 高橋英一：化学と生物, 23, 330 (1985).

3) 魏 復盛, 朱 玉瑞, 沈 乃葵 : 化学試剂, 1, 52 (1980).

4) A. J. Hall, R. S. Young : Anal. Chem., 22, 497 (1950).

5) N. E. Dixon, R. L. Blakeley, B. Zerner : Can. J. Biochem., 58, 469 (1980).

6) W. J. Simmons : Anal. Chem., 45, 1947 (1973)

7) D. W. Dewey, H. R. Marson : Anal. Chim. Acta, 57, 45 (1971).

8) W. J. Simmons : Anal. Chem., 47, 2015 (1975).

9) 札川紀子, 川瀬 晃：分析化学，29，6 (1980).

10) 札川紀子, 川瀬 晃 : 分析化学, 27，37 (1978).

11) A. M. Ure, R. L. Mitchell : Spectrochim. Acta, 23 B, 79 (1967).

12) D. E. Leyden, G. H. Luttrell : Anal. Chem., 47, 1612 (1975).

13）斉交啓, 何 友昭: 中国科学技術大学学報, 增 刊, 65 (1982).

14）斉交啓, 何 友昭: 環境科学情報, 12,9 (1981).

$$
\hat{h}
$$

Determination of cobalt and nickel in plant materials by graphite furnace AAS. Qi WenQI*, Keiichi FuruYA** and Yohichi GoHshi*** (*China University of Science and Technology, Hefei City, the People's Republic of China; **Department of Chemistry, Science University of Tokyo, 1-3, Kagurazaka Shinjuku-ku, Tokyo 162; ***Department of Industrial, Chemistry, University of Tokyo, 7-3-1, Hongo, Bunkyoku, Tokyo 113)

A precise analytical method for using graphite furnace AAS is described for the determination of trace amounts of $\mathrm{Co}$ and $\mathrm{Ni}$ in plant materials. By adding $\mathrm{NH}_{4} \mathrm{VO}_{3}$ as a matrix modifier, direct quantitative determinations of $\mathrm{Co}$ and $\mathrm{Ni}$ are possible without preconcentration or separation of coexisting elements. This method was applied to the determinations of Co and $\mathrm{Ni}$ in Tea and Orchard Leaves (NBS SRM 1570) with satisfactory results. The analytical results of Co were 0.19 $\mu \mathrm{g} / \mathrm{g}$ and $1.35 \mu \mathrm{g} / \mathrm{g}$ on the average for Orchard Leaves and Spinach, respectively, which agreed with the reference value $(0.2 \mu \mathrm{g} / \mathrm{g}$ and $1.5 \mu \mathrm{g} / \mathrm{g})$. The results of $\mathrm{Ni}$ were $1.22 \mu \mathrm{g} / \mathrm{g}$ and $5.68 \mu \mathrm{g} / \mathrm{g}$ respectively on the average for Orchard Leaves and Spinach, which agreed with the value $1.3 \pm 0.2 \mu \mathrm{g} / \mathrm{g}$ and reference value $6 \mu \mathrm{g} / \mathrm{g}$.

(Received December 13, 1986)

\section{Keyword phrases}

AAS; graphite furnace; Co; $\mathrm{Ni}$; plant materials; matrix modifier. 